\title{
PENGARUH SUBSTRAT DAN KEDALAMAN TERHADAP PERTUMBUHAN SPONS (Callyspongia sp.) DI PERAIRAN JEPARA
}

\author{
Bram Setyadji dan Anthony Sisco Panggabean \\ Peneliti pada Balai Riset Perikanan Laut, Muara Baru-Jakarta \\ Teregistrasi I tanggal: 24 Agustus 2010; Diterima setelah perbaikan tanggal: 1 Nopember 2010; \\ Disetujui terbit tanggal: 11 Nopember 2010
}

\begin{abstract}
ABSTRAK
Potensi spons sebagai bioindikator (biomonitoring dan biomarker), bioremidiasi maupun untuk kebutuhan farmasi dan komersial telah banyak diidentifikasi melalui penelitian-penelitian sebelumnya. Penelitian ini bertujuan untuk memberikan informasi dasar mengenai pengaruh faktor lingkungan (substrat dan kedalaman perairan) terhadap pertumbuhan spons Callyspongia sp. Penelitian ini menggunakan metode eksperimental. Hasil penelitian menunjukan rata-rata laju pertumbuhan panjang spons Callyspongia sp. lebih tinggi pada kedalaman $2 \mathrm{~m}$ dibandingkan $1 \mathrm{~m}$ pada substrat ban dan jaring. Hubungan antara spons dengan substrat tidak menunjukan perbedaan yang berarti, sedangkan kedalaman diduga merupakan faktor yang lebih berpengaruh terhadap pertumbuhan spons jenis ini.
\end{abstract}

\section{KATAKUNCI: Callyspongia sp., pertumbuhan, substrat, kedalaman}

ABSTRACT: The effect of substrate and water depth on the growth of Callyspongia sp. in Jepara Waters. By: Bram Setyadji and Anthony Sisco Panggabean

\begin{abstract}
The use of sponge as bioindicator (biomonitoring and biomarker), bioremidiation and pharmaceutical purposes have been widely reported in many studies. However little is known about knowledge of their biological and ecological aspect. The aim of this study was to presents basic information about the influence of substrate and depth on growth of Callyspongia sp. The results showed that the average of length growth of Callyspongia sp. in the water depth $2 \mathrm{~m}$ more higher than $1 \mathrm{~m}$ in both net and tire subtrates here were no differences of growth between net and tire as a substrate, while depth was likely put more influence on the growth of this sponge.
\end{abstract}

\section{KEYWORDS: Callyspongia sp., environmental factor, growth, substrate, depth}

\section{PENDAHULUAN}

Spons merupakan organisme multiselular yang paling primitif. Pada umumnya ditemukan menempel pada pasir, batu-batuan, dan karang mati hampir pada semua tingkat kedalaman. Spons juga dikenal memproduksi metabolit sekunder yang bersifat esensial dari mekanisme pertahanan dan kelangsungan hidup atau dominansi teritorial, hal ini dapat terjadi karena sifat hidup sessile dan filter feeder organisme ini memiliki sistem pertahanan dari pemangsaan predator yang memungkinkan ia bersimbiosis dengan bakteri, jamur, dan alga tertentu untuk menjadi bahan bioaktif (Osinga et al., 1999).

Sejumlah penelitian menunjukan bahwa bahan bioaktif pada spons (Haliclona, Petrosia, dan Discodemia) merupakan penghasil zat anti kanker dan dan anti inflamantory yang kuat (Osinga et al., 1999; Osinga, 2004; Thakur \& Müller, 2004). Dikenal juga adanya anti oksidan yang kuat pada
Callyspongia sp. (Hanani et al., 2005). Biotoksin yang bersifat bakterisida, antara lain pada Auletta sp., Callyspongia sp., C. pseudomonas., dan Halichondria cartilagena yang dapat menghambat perkembangan bakteri Vibrio sp., Pseudomonas sp., Enterobacteriaceae, dan Acinetobactersp. (Ahmad et al., 1995; Muliani \& Suryati, 2002).Spons juga mengandung fungisida (Thionella cylindrical) (Muliani et al., 1998). Selain itu juga berfungsi sebagai antibiofouling terhadap teritip (Balanus amphitrit) (Suryati et al., 1999), dan antifouling pada teknologi kelautan (Osinga et al., 1998).

Pada perkembangannya spons dapat dimanfaatkan sebagai bioindikator, yaitu sebagai biomonitoring dan biomarker, seperti spons jenis Crambe crambe dapat digunakan untuk memantau kontaminasi polutan di perairan, karena dapat mengakumulasi tembaga, timbale, dan vanadium di dalam jaringannya. (Cebrian et al., 2003). Kandungan logam berat dapat dipantau menggunakan Petrosia 
tertudinaria (Rao et al., 2006), sedangkan Suberites domuncula dipakai untuk melihat kondisi lingkungan perairan yang mengalami tekanan dari cadmium dan bakteri (Wagner et al., 1998). Spons berfungsi pula sebagai bioremidiasi karena memiliki kemampuan menyaring $80 \%$ kandungan partikel terlarut di perairan (Stabili et al., 2006).

Kebutuhan akan biomassa spons untuk penelitian maupun produksi komersial tidak akan sebanding dengan yang dapat diambil dari laut, akibatnya hal ini dapat menimbulkan masalah ketersediaan, oleh karena itu dibutuhkan pengetahuan mengenai sifatsifat biologis dan ekologis hewan tersebut. Penelitian ini bertujuan untuk memberikan data dan informasi dasar mengenai pengaruh substrat dan kedalaman terhadap laju pertumbuhan spons Callyspongia sp. Hasil penelitian diharapkan dapat memberikan pengetahuan tambahan dalam memahami aspek biologi dan faktor pembatas pertumbuhan spons, khususnya spesies Callyspongia sp.

\section{BAHAN DAN METODE}

\section{Pengambilan Contoh}

Penelitian ini dilaksanakan pada bulan Juli sampai September 2005 dengan lokasi pengambilan contoh di perairan Bandengan, Jepara (Gambar 1). Pemeliharaan spons dilakukan di perairan Teluk awur, Jepara.

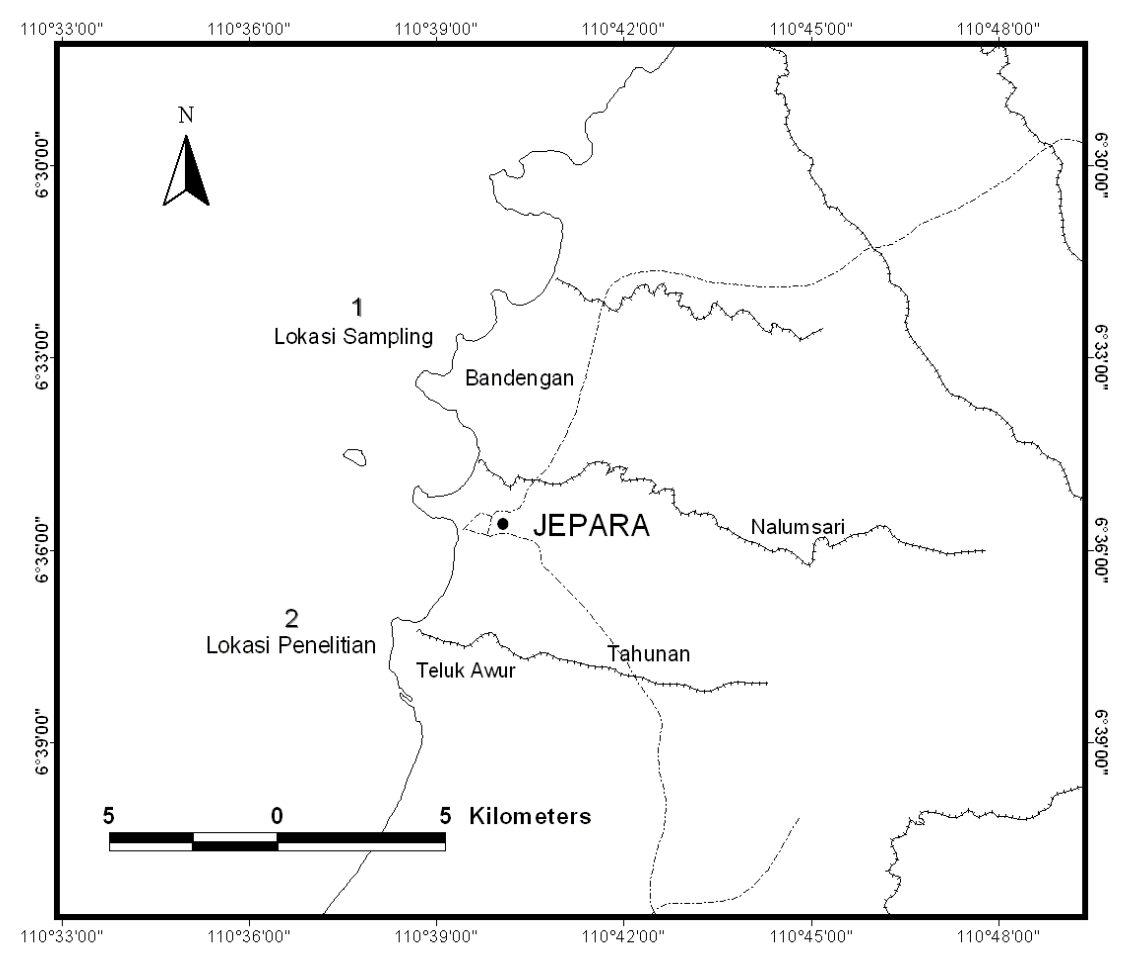

Gambar 1. Peta lokasi pengambilan contoh perairan Bandengan, Jepara.

Figure 1. Map showing sampling site in Bandengan waters, Jepara.

Pengambilan contoh spons Callyspongia sp. dilakukan dengan metode purposive, dengan cara mengambil subyek bukan berdasarkan atas strata, random, atau daerah, tetapi berdasarkan atas tujuan tertentu (Arikunto, 1993). Contoh spons diambil dari perairan Bandengan, Jepara. Spons dan substrat yang diambil diutamakan yang hidup soliter serta tidak menempel pada karang hidup. Contoh spons ditempatkan dalam kantong strimin untuk selanjutnya ditempatkan dalam ember. Proses ini dilakukan sepenuhnya tanpa spons terekspos ke udara, karena memindahkan spons karang dari air, walaupun untuk beberapa detik dapat membunuhnya (Toonen, 1996; Osinga et al., 1999). Selanjutnya spons dalam ember diberi aerasi yang berasal dari aerator baterai dan ditempatkan di tempat yang teduh untuk menghindari kenaikan suhu akibat pemanasan sinar matahari yang dapat menaikan kadar garam dalam ember. 


\section{Perlakuan}

Tiap spons jenis Callyspongiasp. ini diikatkan pada ban yang merupakan media penanaman, di mana ban diberi patok dari besi agar tidak terbawa arus (Gambar 2), Sebagian lain diikatkan pada jaring yang sudah diset, sehingga jaring dapat berdiri dengan menggunakan besi sebagai penegak sekaligus menjaga agar jaring tersebut tidak terbawa arus (Gambar 3). Kedua cara penanaman tersebut diulang tiga kali dan diletakan pada kedalaman yang berbeda, yaitu pada kedalaman 1 dan $2 \mathrm{~m}$ (diukur pada saat surut terendah). Pengukuran panjang dan diameter spons. Pengukuran dilakukan tiap satu minggu selama enam minggu.

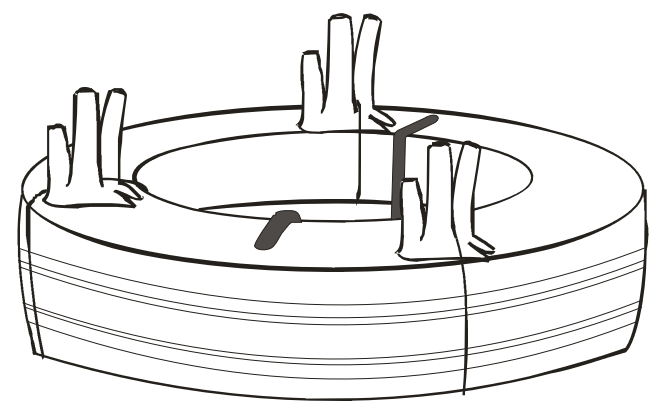

Gambar 2. Penanaman spons dengan media ban.

Figure 2. Planting sponge on tyre substrate.

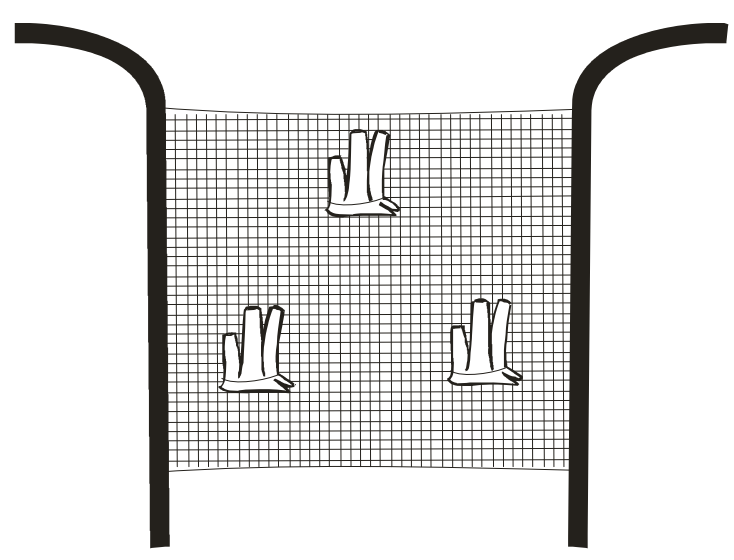

Gambar 3. Penanaman spons dengan media jaring.

Figure 3. Plating sponge on net substrate.

Sebagai data pendukung dilakukan penerapan kualitas air, yaitu suhu, salinitas, $\mathrm{pH}$, arus, kecerahan masing-masing diukur dengan suhu, hand refraktometer, $\mathrm{pH}$-meter, bola duga, dan secchi disc. Laju sedimentasi diduga mengikuti cara (Supriharyono, 1990). Seluruh pengukuran kualitas air dilakukan setiap dua minggu.

\section{Analisis Data}

Data yang dianalisis meliputi data pertambahan panjang dan diameter spons. Pertumbuhan spons yang didasarkan atas pertambahan panjang dan diameter dihitung dengan mengukur panjang dan diameter rata-rata dari jumlah dan perubahan nilai ratarata sesuai periode waktu pengukuran (Supriharyono,
2000) dengan rumus sebagai berikut:

$$
\mathrm{L}_{\mathrm{t}}=\mathrm{L}_{1}-\mathrm{L}_{0}
$$

di mana:

$\mathrm{L}_{\mathrm{t}}=$ pertambahan panjang

$\mathrm{L}_{0}=$ panjang awal

$\mathrm{L}_{1}=$ panjang akhir

Penentuan laju pertumbuhan panjang mingguan dihitung dengan modifikasi perasamaan Duckworth et al. (1997):

Laju pertumbuhan $=$ (panjang akhir-panjang awal) $\times 100 \%$ 


\section{HASIL DAN BAHASAN}

\section{Pertumbuhan Callyspongia sp.}

Rata-rata laju pertumbuhan spons Callyspongiasp. lebih tinggi pada kedalaman $2 \mathrm{~m}$ dibandingkan $1 \mathrm{~m}$ pada kedua perlakuan (Tabel 1). Pertumbuhan lebih baik kedalaman $2 \mathrm{~m}$ dengan media jaring yaitu $30,45 \%$ dibandingkan dengan ban pada kedalaman yang sama yaitu $14,77 \%$.
Hasil penelitian menunjukan bahwa penanaman menggunakan substrat jaring maupun ban tidak menunjukan pengaruh yang berarti (Gambar 4). Laju pertumbuhan spons jenis ini diduga lebih banyak dipengaruhi oleh kedalaman perairan karena Callyspongia sp. banyak tumbuh pada perairan yang agak dalam (9-12 m) (Suharyanto, 2008).

Tabel 1. Laju pertumbuhan spons Callyspongia sp. dengan cara penanaman dan kedalaman yang berbeda selama penelitian

Table 1. Growth rate of sponge Callyspongia sp. based on substrate and depth treatments

\begin{tabular}{|c|c|c|c|c|c|}
\hline \multicolumn{2}{|c|}{ Perlakuan/Treatment } & & \multicolumn{2}{|c|}{ Pengukuran/Measurement $(\mathrm{cm})$} & \multirow{2}{*}{$\begin{array}{c}\text { Laju } \\
\text { pertumbuhan/ } \\
\text { Growth rate, } \\
\text { GR }(\%)\end{array}$} \\
\hline $\begin{array}{c}\text { Cara penanaman/ } \\
\text { How to planting }\end{array}$ & $\begin{array}{c}\text { Kedalaman/Depth } \\
\text { (m) }\end{array}$ & & Awal/Early & Akhir/Ending & \\
\hline \multirow{4}{*}{ Jaring } & \multirow{2}{*}{1} & Panjang & 8,30 & 9,63 & 14,35 \\
\hline & & Diameter & 3,10 & 4,46 & 30,00 \\
\hline & \multirow{2}{*}{2} & Panjang & 6,07 & 7,99 & 30,45 \\
\hline & & Diameter & 2,24 & 3,40 & 35,09 \\
\hline \multirow{4}{*}{ Ban } & \multirow{2}{*}{1} & Panjang & 12,87 & 15,04 & 14,44 \\
\hline & & Diameter & 5,82 & 7,17 & 22,16 \\
\hline & \multirow{2}{*}{2} & Panjang & 8,42 & 9,90 & 14,77 \\
\hline & & Diameter & 2,84 & 4,43 & 34,29 \\
\hline
\end{tabular}

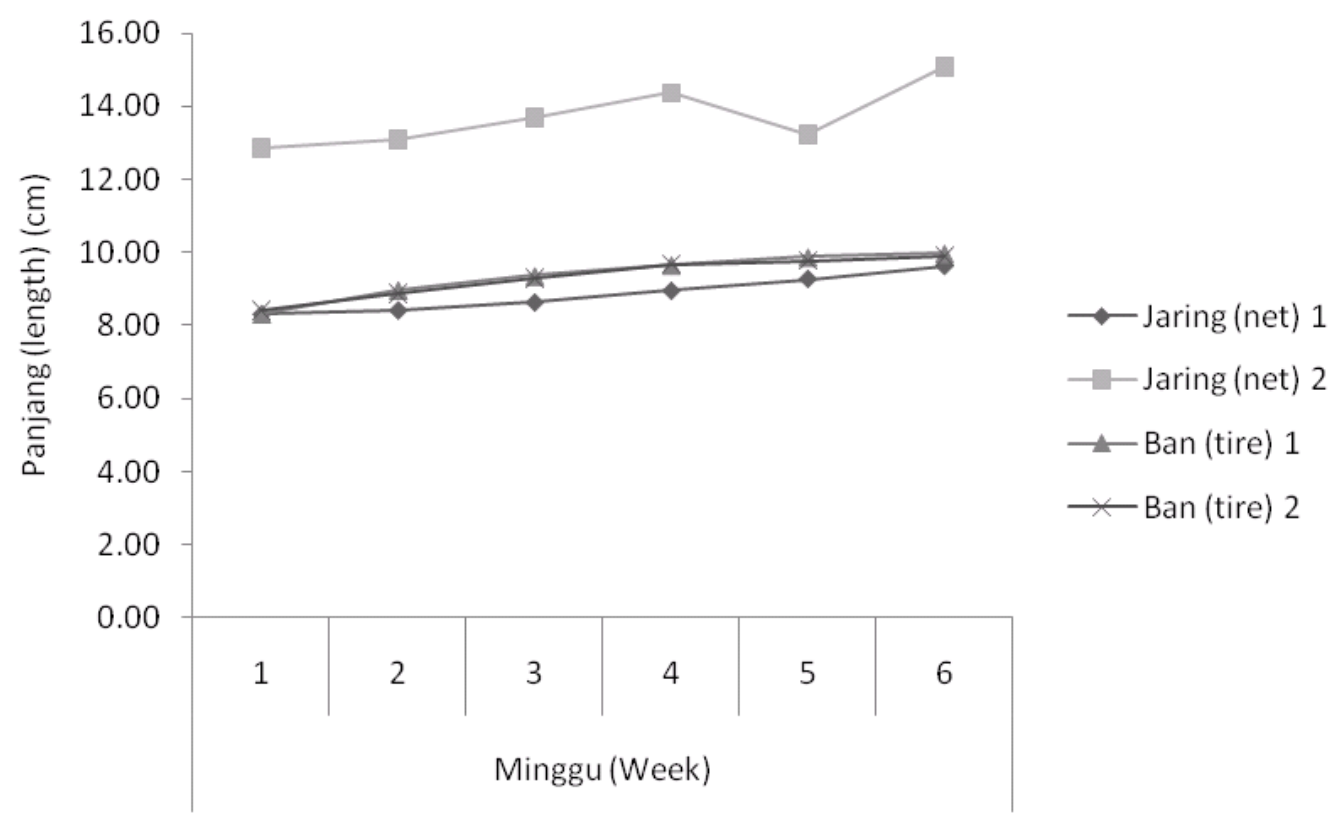

Gambar 4. Laju pertumbuhan panjang mingguan spons (Callyspongia sp.) pada substrat dan kedalaman yang berbeda.

Figure 4. Weekly growth rate for length of sponge (Callyspongia sp.) on different substrates and depths. 
Pengamatan secara visual, menunjukan bahwa tumbuhan Callyspongia sp. cenderung melebar (tumbuh ke arah samping), ditandai oleh pertambahan diameter yang lebih besar daripada pertambahan panjang (Gambar 5). Pertumbuhan spons jenis ini bertipe free standing dengan bentuk morfologi seperti vas yang bercabang, sehingga pertumbuhan $k e$ atas (panjang) lebih dominan daripada pertumbuhan ke samping. Hal ini berbeda dengan tipe encrusting, di mana pertumbuhan ke samping lebih dominan akibat adanya proses adaptasi terhadap ketersediaan tempat, substrat, dan kecepatan arus (Rupert \&
Barnes, 1994 dalam Pong-Masak \& Rachmansyah, 2002). Menurut Bond \& Harris (1988); Amir \& Budiyanto (1996) spons dapat tumbuh baik pada perairan yang tenang maupun berarus. Sedangkan spons yang hidup pada lingkungan yang bergelombang atau arus yang kuat, spons dapat merubah bentuk morfologi tubuhnya dengan tumbuh secara merambat. Porifera misalnya, memiliki kemampuan untuk beradaptasi secara morfologis maupun fisiologis karena adanya pengaruh dari lingkungan hidupnya.

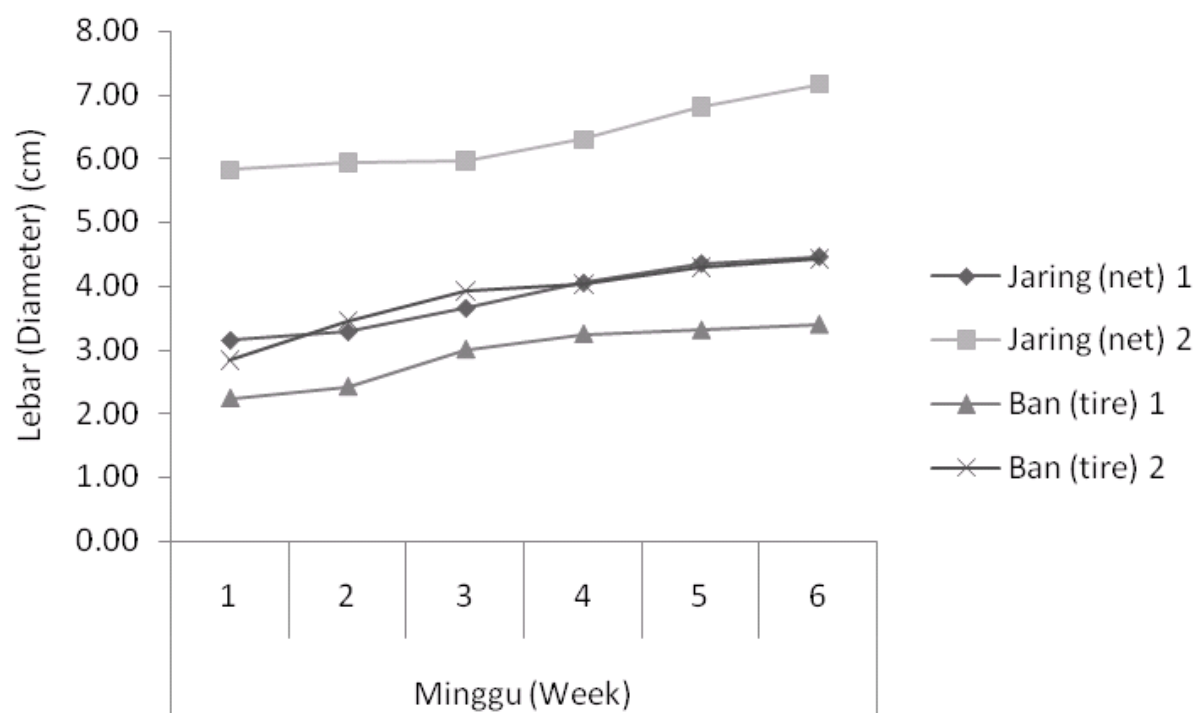

Gambar 5. Laju pertumbuhan diameter mingguan spons (Callyspongia sp.) pada substrat dan kedalaman yang berbeda.

Figure 5. Weekly growth rate for width of sponge (Callyspongia sp.) on different substrates and depths.

\section{Peranan Substrat}

Substrat memiliki pengaruh besar terhadap pertumbuhan spons, karena cara hidupnya bersifat menetap dan nyaris tanpa pergerakan (Bond \& Harris, 1988). Seperti halnya hewan sessile, spons lebih menyukai substrat yang keras atau kasar (Toonen, 1996). Jaring sebagai substrat telah banyak digunakan dalam beberapa penelitian (Duckworth et al., 1997; Duckworth \& Battershill, 2004; Pong-Masak \& Rachmansyah, 2002). Dibandingkan dengan substrat dari ban bekas, substrat jaring mempunyai beberapa keuntungan apabila digunakan pada lingkungan yang berarus tinggi. Pada substrat jaring lumut dan tumbuhan epifit lain akan mudah menempel. Pada perairan yang mempunyai gelombang tinggi lumut dan partikel tersuspensi akan sulit menempel (Susanto, 2005). Sehingga penggunaan jaring sebagai media tanam bagi spons lebih baik karena selain jaring bersih dari lumut dan partikel tersuspensi juga akan mencegah spons terbawa oleh arus. Metode jaring sebaiknya digunakan untuk spons yang lunak agar tidak hancur atau rusak dan dapat tumbuh dengan baik selama proses transplantasi (Duckworth \& Battershill, 2004).

\section{Kualitas Air}

Kondisi oseanografi pada umumnya berpengaruh terhadap kehidupan spons. Suhu rata-rata pada lokasi penelitian $27,11^{\circ} \mathrm{C}$. Kisaran yang optimal bagi pertumbuhan spons yaitu $>18^{\circ} \mathrm{C}$, suhu rata-rata tahunan berkisar antara $23-25^{\circ} \mathrm{C}$, dengan suhu maksimal yang dapat ditolerir berkisar antara $36-40^{\circ} \mathrm{C}$. Salinitas dan suhu perairan secara umum berhubungan dengan pertumbuhan dan kelulushidupan spons (Duckworth et al., 2004). Salinitas yang diukur secara insitu berada pada kisaran $33,4 \%$ 。 Spons tidak dapat hidup pada kondisi di luar salinitas normal, yaitu antara 25-35\% (Nybakken, 1992). 
Derajat keasaman $(\mathrm{pH})$ dapat dikatakan memadai untuk pertumbuhan spons Callspongia sp. Pada saat penelitian diperoleh $\mathrm{pH}=8$ yang berarti air bersifat mendekati normal. Menurut Spotte (1993) kisaran yang sesuai bagi pertumbuhan spons antara 8,0-8,3. Beberapa nilai parameter kualitas perairan yang diamati pada pertumbuhan spons di lokasi penelitian tertera pada Tabel 2.

Tabel2. Parameter kualitas air di perairan Jepara selama penelitian

Table 2. $\quad$ Parameters of water quality in Jepara waters during the research

\begin{tabular}{ccccccc}
\hline & \multicolumn{5}{c}{ Parameter lingkungan/Environmental parameters } \\
\cline { 2 - 7 } $\begin{array}{c}\text { Pengukuran/ } \\
\text { Measurement }\end{array}$ & $\begin{array}{c}\text { Suhu/ } \\
\text { Temperature } \\
\left({ }^{\circ} \mathbf{C}\right)\end{array}$ & $\begin{array}{c}\text { Salinitas/ } \\
\text { Salinity } \\
(\% \circ)\end{array}$ & $\mathbf{p H}$ & $\begin{array}{c}\text { Arus/ } \\
\text { Current } \\
(\mathbf{m} / \mathbf{d t})\end{array}$ & $\begin{array}{c}\text { Laju } \\
\text { sedimentasi/ } \\
\text { Sedimentation } \\
\text { rate } \\
\left(\mathbf{m g} / \mathbf{m}^{2} / \mathbf{h a r i}\right)\end{array}$ & $\begin{array}{c}\text { Kecerahan/ } \\
\text { Brightness }\end{array}$ \\
\hline 1 & 27,33 & 35,00 & 8 & 0,04 & 1,2109 & Sampai dasar \\
2 & 27,00 & 33,33 & 8 & 0,04 & 1,2834 & Sampai dasar \\
3 & 27,00 & 32,00 & 8 & 0,03 & 1,3014 & Sampai dasar \\
\hline Rata-rata & $\mathbf{2 7 , 1 1}$ & $\mathbf{3 3 , 4 4}$ & $\mathbf{8}$ & $\mathbf{0 , 0 4}$ & $\mathbf{1 , 2 6 5 2}$ & Sampai dasar \\
\hline
\end{tabular}

\section{KESIMPULAN}

1. Hubungan antara penggunaan ban bekas dan jaring sebagai substrat pada pertumbuhan spons jenis Callyspongia sp. tidak menunjukan perbedaan yang berarti. Kedalaman perairan diduga lebih berpengaruh terhadap pertumbuhan spons.

2. Rata-rata laju pertumbuhan panjang mingguan Callyspongia sp. pada substrat jaring kedalaman $2 \mathrm{~m}$ lebih tinggi daripada kedalaman $1 \mathrm{~m}$ yaitu $30,45 \%$.

3. Rata-rata laju pertumbuhan panjang mingguan Callyspongia sp. pada substrat ban kedalaman 2 $\mathrm{m}$ lebih tinggi daripada kedalaman $1 \mathrm{~m}$ yaitu $14,77 \%$.

4. Faktor lingkungan yang berpengaruh terhadap pertumbuhan spons Callyspongia sp. adalah kedalaman perairan.

\section{PERSANTUNAN}

Tulisan ini merupakan kontribusi dari kegiatan riset kelompok studi farmakologi laut di Fakultas Perikanan dan Ilmu Kelautan, Universitas Diponegoro, Semarang.

\section{DAFTAR PUSTAKA}

Ahmad, T., Suryati, E. \& Muliani. 1995. Sponges bioactive screening for bactericide in shrimp culture. Indonesian Fisheries Research Journal. 1 (1): 110.
Amir, I. \& A. Budiyanto. 1996. Mengenal spons laut (Demospongiae) secara umum. Oseana. XXI (2): 1996: 15-31.

Arikunto, S. 1993. Prosedur Penelitian: Suatu Pendekatan Praktek. Edisi Revisi II. Penerbit Rineka Cipta. Jakarta.

Bond, C. \& A. K. Harris. 1988. Locomotion of sponges and its physical mechanism. Journal of Experimental Zoology. 246: 271-284.

Cebrian, E., E. Mart, J. M. Uriz, \& X. Turon. 2003. Sublethal effects of contamination on the Mediterranean sponge Crambe crambe: Metal accumulation and biological responses. Marine Pollution Bulletin. 46: 1,273-1,284.

Duckworth, A. R., C. N. Battershill, \& P. R. Bergquist. 1997. Influence of explants procedures on culture success of three sponges. Journal of Aquaculture. 156: 251-267.

Duckworth, A. R. \& C. N. Battershill. 2004. Effects of depth and water flow on growth, survival, and bioactivity of two temperate sponges cultured in different season. Journal of Aquaculture. 242: 237250 .

Duckworth, A. R., C. N. Battershill, \& D. R. Schiel. 2004. Effects of depth and water flow on growth, survival, and bioactivity of two temperate sponges cultured in different season. Journal of Aquaculture. 242: 237-250. Elsevier. 
Hanani, E., A. Mun'im, \& R. Sekarini. 2005. Identifikasi senyawa antioksidan dalam spons Callyspongia sp. dari Kepulauan Seribu. Majalah IImu Kefarmasian. II (3): 127-133.

Muliani, S. E., A. Tompo, A. Parenrengi, \& Rosmiati. 1998. Isolasi biaktif bunga karang sebagai fungisida pada benih udang windu Penaeus monodon. Jurnal Penelitian Perikanan Indonesia. IV (2): 13-23.

Muliani \& E. Suryati. 2002. Efektivitas penggunaan bioaktif spons untuk penanggulangan bakteri Aeromonas sp. pada nener bandeng, Chanos chanos Forskal. Jurnal Penelitian Perikanan Indonesia. 8 (2): 61-66.

Nybakken, J. W. 1992. Biologi Laut: Suatu Pendekatan Ekologi. P. T. Gramedia. Jakarta. 459 pp.

Osinga, R., J. Tramper, \& R. H. Wijffels. 1998. Cultivation of marine sponges for metabolite production: Applications for biotechnology? Tibtech. March 1998 (Vol.16). Elsevier Science Ltd.

Osinga, R., J. Tramper, \& R. H. Wijffels. 1999. Cultivation of marine sponges. Mar. Biotechnol. I. Springer-Verlag New York Inc. 509-532.

Osinga, R. 2004. Cultivation of Functional Sponges in Bioreactors. South Australian Research and Development Institute. www. ftns. wau-nl. Juli 2004.

Pong-Masak, P. R. \& Rachmansyah. 2002. Pertumbuhan spons (Auletta sp.) secara transplantasi dengan panjang benih berbeda. Jurnal Penelitian Perikanan Indonesia. 8 (5): 49-54.

Rao, J. V., P. Kavitha, N. C. Reddya, \& T. G. Rao. 2006. Petrosia testudinaria as a biomarker for metal contamination at Gulf of Mannar, southeast coast of India. Chemosphere. Issue 4. 65: 634-638.

Spotte, S. 1993. Marine Aquarium Keeping. $2^{\text {nd }}$ Edition. John Wiley \& Sons. New York. XV+171.
Stabili, L., M. Licciano, A. Giangrande, C. Longo, M. Mercurio, C. N. Marzano, \& G. Corriero. 2006. Filtering activity of Spongia officinalis var. adriatica (Schmidt) (Porifera, Demospongiae) on bacterioplankton: Implications for bioremediation of polluted seawater. Water Research. Issue 16. 40:3,083-3,090.

Suharyanto. 2008. Distribusi dan persentase tutupan sponge (Porifera) pada kondisi terumbu karang dan kedalaman yang berbeda di perairan Pulau Barranglompo, Sulawesi Selatan. Biodiversitas. 9 (3): 209-212.

Supriharyono. 1990. Hubungan Tingkat Sedimentasi dengan Hewan Makrozoobenthos di Perairan Muara Sungai Moro Demak, Kabupaten Demak. Lembaga Penelitian Universitas Diponegoro. Semarang. $59 \mathrm{pp}$.

Supriharyono. 2000. Pengelolaan Ekosistem Terumbu Karang. Djambatan. Jakarta.

Suryati, E., A. Parenrengi, \& Rosmiati. 1999. Penapisan serta analisis kandungan bioaktif sponge Clathria sp. yang efektif sebagai antibiofouling pada teritip (Balanus amphitrit). Jurnal Penelitian Perikanan Indonesia. V (3): 4761.

Susanto, A. B. 2005. Metode lepas dasar dengan model Cidaun pada budi daya Eucheuma spinosum (Linnaeus) Agardh. Jurnal IImiah IImu Kelautan. Universitas Diponegoro. 10 (3): 158-164.

Thakur, N. L. \& W. G. Müller. 2004. Biotechnological potential of marine sponges. Current Science. 86 (11): $1,506-1,512$.

Toonen, R. J. 1996. A Reefkeeper's Guide to Introductory Invertrebrate Zoology. Part I. Sponges. Aquarium. net. Cybermagazine. November 1996.

Wagner, C., R. Steffen, C. Koziol, R. Batel, M. Lacorn, H. Steinhart, T. Simat, \& W. E. G. Müller. 1998. Apoptosis in marine sponges: A biomarker for environmental stress (cadmium and bacteria). Journal of Marine Biology. 131 (3): 411-421. 